\title{
Model-based optimization and scale-up of multi-feed simultaneous saccharification and co-fermentation of steam pre-treated lignocellulose enables high gravity ethanol production
}

Ruifei Wang ${ }^{1}$, Pornkamol Unrean ${ }^{1,2}$ and Carl Johan Franzén ${ }^{1 *}$

\begin{abstract}
Background: High content of water-insoluble solids (WIS) is required for simultaneous saccharification and co-fermentation (SSCF) operations to reach the high ethanol concentrations that meet the techno-economic requirements of industrial-scale production. The fundamental challenges of such processes are related to the high viscosity and inhibitor contents of the medium. Poor mass transfer and inhibition of the yeast lead to decreased ethanol yield, titre and productivity. In the present work, high-solid SSCF of pre-treated wheat straw was carried out by multi-feed SSCF which is a fed-batch process with additions of substrate, enzymes and cells, integrated with yeast propagation and adaptation on the pre-treatment liquor. The combined feeding strategies were systematically compared and optimized using experiments and simulations.
\end{abstract}

Results: For high-solid SSCF process of $\mathrm{SO}_{2}$-catalyzed steam pre-treated wheat straw, the boosted solubilisation of WIS achieved by having all enzyme loaded at the beginning of the process is crucial for increased rates of both enzymatic hydrolysis and SSCF. A kinetic model was adapted to simulate the release of sugars during separate hydrolysis as well as during SSCF. Feeding of solid substrate to reach the instantaneous WIS content of $13 \%(\mathrm{~W} / \mathrm{W})$ was carried out when $60 \%$ of the cellulose was hydrolysed, according to simulation results. With this approach, accumulated WIS additions reached more than $20 \%(\mathrm{w} / \mathrm{w}$ ) without encountering mixing problems in a standard bioreactor. Feeding fresh cells to the SSCF reactor maintained the fermentation activity, which otherwise ceased when the ethanol concentration reached $40-45 \mathrm{~g} \mathrm{~L}^{-1}$. In lab scale, the optimized multi-feed SSCF produced $57 \mathrm{~g} \mathrm{~L}^{-1}$ ethanol in $72 \mathrm{~h}$. The process was reproducible and resulted in $52 \mathrm{~g} \mathrm{~L}^{-1}$ ethanol in $10 \mathrm{~m}^{3}$ scale at the SP Biorefinery Demo Plant.

Conclusions: SSCF of WIS content up to $22 \%(\mathrm{w} / \mathrm{w})$ is reproducible and scalable with the multi-feed SSCF configuration and model-aided process design. For simultaneous saccharification and fermentation, the overall efficiency relies on balanced rates of substrate feeding and conversion. Multi-feed SSCF provides the possibilities to balance interdependent rates by systematic optimization of the feeding strategies. The optimization routine presented in this work can easily be adapted for optimization of other lignocellulose-based fermentation systems.

Keywords: Biofuels, Fermentation technology, Agricultural residues, Bioprocessing, Enzymatic hydrolysis, High gravity, Demo-scale simultaneous saccharification and fermentation, Mathematical modelling, Fed-batch SSF

\footnotetext{
*Correspondence: franzen@chalmers.se

${ }^{1}$ Division of Industrial Biotechnology, Department of Biology

and Biological Engineering, Chalmers University of Technology,

Gothenburg, Sweden

Full list of author information is available at the end of the article
} 


\section{Background}

Agricultural residues such as wheat straw are attractive raw materials for fuel ethanol production since they may allow high resource efficiency while avoiding the competition for crops between food and fuel production. A promising process configuration for ethanol production from lignocellulosic feedstock is simultaneous saccharification and fermentation (SSF). In SSF, the enzymatic hydrolysis of the pre-treated biomass occurs simultaneously with the fermentation. SSF offers several advantages compared to separate hydrolysis and fermentation, including reduced end-product inhibition of hydrolytic enzymes caused by accumulated sugars and reduced operating cost because of the lower number of reactors needed. It has been estimated that the capital investment can be reduced by more than $20 \%$ with SSF compared to separate hydrolysis and fermentation processes [1]. SSF also favours co-fermentation (SSCF) of glucose and xylose by recombinant Saccharomyces cerevisiae, because the concentration of glucose can be kept low due to balanced rates of release and consumption by hydrolysis and fermentation [2].

Efficient and economical production of lignocellulosic ethanol requires high ethanol titres, since separation and rectification of the ethanol accounts for the major energy demand, in some cases more than $80 \%$ [3]. The distillation cost can be reduced by operating SSF and SSCF at high content of water-insoluble solids (WIS), which means high sugar input and potentially high ethanol titre. Techno-economic models have predicted that increasing the insoluble solids content from 7 to $15 \%(\mathrm{w} / \mathrm{w})$ in a SSF process could reduce the energy demand by half at the same ethanol yield [3]. However, operation of SSF/SSCF at high solid concentration presents challenges such as high viscosity, resulting in low efficiency in mass and heat transfer and high power consumption for mixing. In addition, high substrate content also gives high concentrations of inhibitors, which affect the ethanol yield, titre and productivity negatively [4-7].

Using high enzyme dosage could accelerate saccharification and reduce viscosity quickly for high-WIS SSF/ SSCF. However, the environmental impact and process economy of lignocellulosic ethanol are significantly affected by the enzyme usage [3, 8]. A fed-batch approach is preferred in this context since it allows relatively high enzyme to substrate ratios throughout the process by gradual addition of substrate. This has enabled substrate loadings up to $20 \%(\mathrm{w} / \mathrm{w})$ WIS in SSF and SSCF, and given relatively high final titres of ethanol up to $40 \mathrm{~g} \mathrm{~L}^{-1}$ with intermediate levels of enzymes $[9,10]$.

The smooth operation of fed-batch SSCF relies on balanced rates of substrate loading, hydrolysis and fermentation. Even though such balances are crucial for efficient mixing and productivity, they are difficult to achieve since every single rate in the SSCF context is interconnected with other rates via shared compounds. The full outcome of changes in one part of the process cannot be easily foreseen from intuition, nor easily derived from previous experience. Various strategies for fed-batch operation have been proposed, including controlled feeds of substrate, enzymes and cells [2, 9-13]. Yet, no systematic optimization of multiple feeding strategies for fedbatch SSCF has been reported, nor have they been tested in large-scale trials.

In this study, we carefully assessed the effects of substrate, enzyme and cell feeds on SSCF of $\mathrm{SO}_{2}$-catalyzed steam pre-treated wheat straw. We designed fed-batch profiles for high solid content processes by balancing the addition and hydrolysis of solid substrates via mathematical modelling and a control loop for determining the solid feeds. With such a model-driven approach, which predicted the dynamic outcomes of the feeds, we established balanced fed-batch SSCF by developing suitable feeding strategies regarding enzymes, substrates and cells. The process, termed multi-feed SSCF as it involved multiple feed streams, was scaled up to $10 \mathrm{~m}^{3}$ scale.

The objective was to improve ethanol production from pre-treated wheat straw by increasing the cumulative loading of water-insoluble solids (WIS), decreasing the enzyme usage and establishing procedures for yeast propagation with maximal use of pre-treatment liquor. The systematic optimization of multi-feed SSCF illustrated the important factors contributing to high ethanol titres. The optimization routine may be transferred to other lignocellulose-based processes.

\section{Results and discussion}

\section{Overall scheme of multi-feed SSCF and strategy for optimization}

The underlying hypothesis of this work was that efficient SSCF depends on balanced rates of the major reactions occurring within an SSCF, and that such balance can be achieved by controlling the rates of multiple feeds. The systematic optimization included three dimensions: feeding or not feeding enzymes; detailed solid feed profile and feeding or not feeding cells (Fig. 1). For enzymes and cells, comparison experiments were carried out and choices were made based on the results. For solids, feeding profiles were designed based on simulated rates of hydrolysis and fermentation, and the precondition that the broth viscosity had to be maintained low enough to enable good mixing.

\section{Yeast propagation in pre-treatment liquor is a compromise} between high cell yield and high fermentation capacity

Cells adapted to the pre-treatment liquor during propagation have shown improved performance in SSF/SSCF [14-16]. Here, the objective was to optimize the addition 


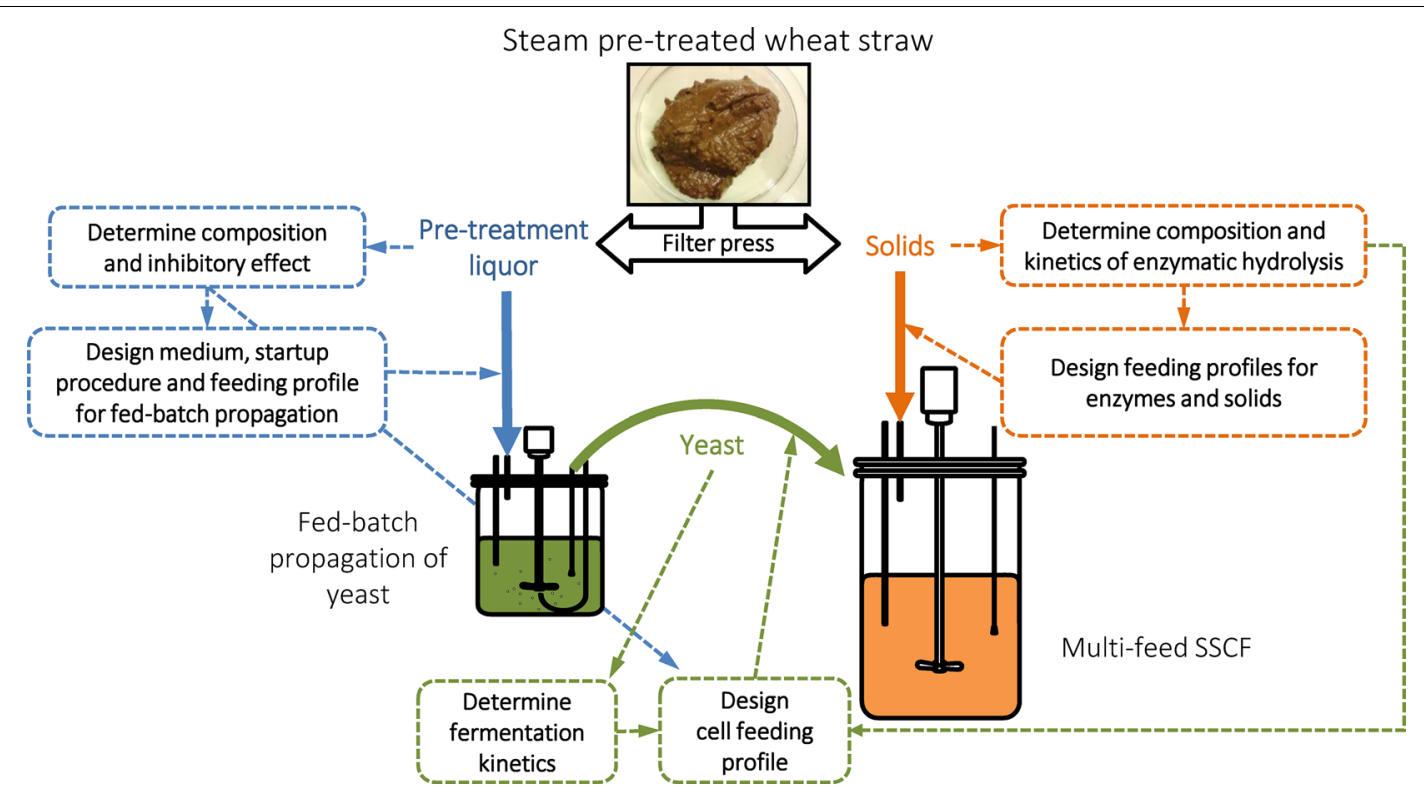

Fig. 1 Scheme of multi-feed SSCF and process optimization targets. Pre-treated wheat straw from SP Biorefinery Demo Plant (BDP) contained WIS about 15-20\% (w/W). Separating solid from liquid fraction of the slurry by centrifugation (in lab) or filter press (in the plant) gave a solid fraction with about $40 \%(\mathrm{w} / \mathrm{W}$ ) WIS content. The multi-feed SSCF used solid fraction as substrate and allowed operation above $20 \%$ (w/w) WIS. The liquid fraction was used for yeast propagation

of pre-treatment liquor to the medium and, hence, increase the adaptation pressure during cell propagation while still having rapid cell growth and high cell yield. The liquid fraction of pre-treated wheat straw contains oligomeric and monomeric sugars, and inhibitors that are formed during pre-treatment. The pre-treatment liquor can partly replace sugars and fresh water for cell production. However, it has been shown that yeast growth commences only after depletion of furfural and hydroxymethylfurfural $[14,17]$. Therefore, higher level of pre-treatment liquor would lead to longer lag phase. In an industrial context, such lag phases must be avoided. Thus, the operation parameters for cell propagation are a compromise between yield, productivity and adaptation to the inhibitors.

The cell propagation consisted of batch and fed-batch phases, and we optimized the medium composition for each phase (Fig. 2). In the batch phase, cell growth in $10 \%(\mathrm{v} / \mathrm{v})$ pre-treatment liquor medium was very similar to growth in the pre-treatment liquor-free medium, suggesting that at $10 \%(\mathrm{v} / \mathrm{v})$, this particular pre-treatment liquor was not toxic enough to affect cell growth. In $20 \%(\mathrm{v} / \mathrm{v})$ pre-treatment liquor medium, however, yeast cells grew only after a 12-h lag phase and the cell yield after 24 h was approximately $40 \%$ lower than the yield obtained in $10 \%(\mathrm{v} / \mathrm{v})$ medium. In medium containing $30 \%(\mathrm{v} / \mathrm{v})$ pre-treatment liquor or more, no growth was observed within $24 \mathrm{~h}$. Therefore, among the tested pretreatment liquor contents in batch media, $20 \%(\mathrm{v} / \mathrm{v})$ was chosen as it imposed a significant pressure on cells for adaptation, while allowing sufficient cell growth in 1 day (Fig. 2a).

After the 24-h batch phase, yeast propagation was continued with fed-batch cultivation. High contents (50 and $80 \%, \mathrm{v} / \mathrm{v}$ ) of pre-treatment liquor were used in the feed medium and fed at dilution rates of 0.05 and $0.075 \mathrm{~h}^{-1}$. A higher fraction of pre-treatment liquor in the feed or a higher dilution rate may be positive for cell production and adaptation. However, it may also induce overflow metabolism and more sugar consumed for in situ detoxification, either of which reduces the biomass yield on sugars. Decreased cell yield and productivity were indeed observed with increasing fraction of pre-treatment liquor and increasing dilution rate (Fig. 2b). At the end of the fed-batch, residual ethanol was found in all cases except for the $50 \%(\mathrm{v} / \mathrm{v})$ pre-treatment liquor medium fed at $0.05 \mathrm{~h}^{-1}$. Furfural accumulation occurred at approximately $0.3 \mathrm{~g} \mathrm{~L}^{-1}$ when $80 \%(\mathrm{v} / \mathrm{v})$ pre-treatment liquor medium was used throughout the fed-batch phase. Therefore, $50 \%(\mathrm{v} / \mathrm{v})$ pre-treatment liquor in the feed and a dilution rate of $0.05 \mathrm{~h}^{-1}$ were chosen as they gave the highest overall cell yield and cell production rate, $0.39 \mathrm{~g} \mathrm{~g}^{-1}$ and $0.25 \mathrm{~g}(\mathrm{~L} \mathrm{~h})^{-1}$, respectively, in the fedbatch (Fig. 2b). 

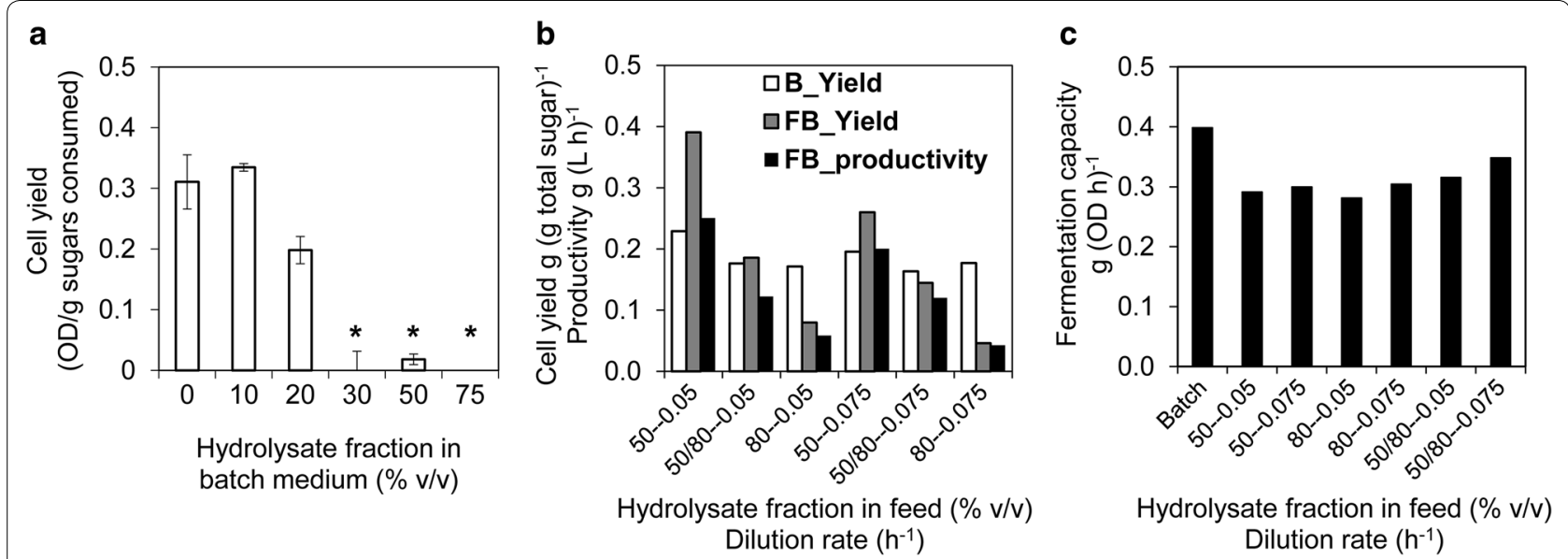

Fig. 2 Optimization of seed cultivation in wheat straw pre-treatment liquor medium. a Effect of pre-treatment liquor concentration (\% $v / v$ ) on cell yield after $24 \mathrm{~h}$ shake flask batch cultivation. The asterisks indicate that yeast growth was not sufficient to calculate the yield. Error bars indicate standard deviation of duplicate experiments. b Effects of the feed rate and the pre-treatment liquor concentration (\% v/v) in feed medium on cell growth during fed-batch cultivation. Fed batch was started after a 24-h batch phase in $20 \%$ (v/v) pre-treatment liquor medium. B_Yield, cell yields over the batch phase. FB_Yield, overall cell yield over the fed-batch phase, FB_Productivity, average cell productivity over the fed-batch phase. c Fermentation capacity of cells after batch and fed-batch cultivation. The conditions for seed cultivation in the subsequent multi-feed experiments were $20 \%(\mathrm{v} / \mathrm{v})$ pre-treatment liquor batch cultivation, followed by $50 \%$ ( $/ \mathrm{v}$ ) pre-treatment liquor fed-batch cultivation at feed rate of $0.05 \mathrm{~h}^{-1}$

The quality of yeast cells is crucial for fermentation processes. To evaluate cell quality, we determined the fermentation capacity in the presence of inhibitors (Fig. 2c). Cells prepared in the different fed-batch processes all had similar fermentation capacity, suggesting that the product quality did not depend on the feed rate and pretreatment liquor concentration in the fed-batch phase. However, cells from batch cultivation showed higher ethanol productivity compared to those from fed-batch cultures, which had $70 \%$ capacity of batch-cultured cells (Fig. 2c). This was likely because cells grew at higher specific growth rate in the respiro-fermentative batch phase, compared to the fed-batch phase [18]. The lower capacity might also be a result of reduced concentrations of inhibitors in the fed-batch culture due to in situ detoxification, which would lead to lower adaptive pressure in fed-batch propagation.

\section{Initial loading of all enzyme and model-based feeding of solids enabled rapid enzymatic hydrolysis at high solid loading}

The efficiency of enzymatic hydrolysis relies on the properties of the pre-treated substrate, the activities of the enzyme cocktail and the process setup. We determined the enzyme dosage and the mode of enzyme addition based on the glucose release in batch and fed-batch hydrolysis experiments, respectively. We also developed substrate feed profiles using a control loop based on kinetic modelling. The results of hydrolysis experiments are summarized in Additional file 1: Table S1.
$10 \%$ (w/w) WIS batch hydrolysis was carried out in bioreactors at the enzyme dosages 5,10 and 15 FPU (g WIS $)^{-1}$. The glucose yield after $96 \mathrm{~h}$ of hydrolysis was improved by $20 \%$ when increasing the enzyme dosage from 5 to $10 \mathrm{FPU}$ $(\mathrm{g} \mathrm{WIS})^{-1}$, and a further increase of $9 \%$ was obtained with $15 \mathrm{FPU}$ (g WIS $)^{-1}$ compared to the $10 \mathrm{FPU}$ case (Fig. 3a, b). Given these results, 10 FPU (g WIS) ${ }^{-1}$ enzyme dosage was selected for all following studies.

In fed-batch hydrolysis, loading all enzyme at time 0 clearly showed the advantage of boosting the initial hydrolytic rate and liquefaction of solid substrates, compared to gradual feeding of enzymes. Faster hydrolysis also resulted in more complete release of sugars from their polymeric forms. In experiments of $15 \%$ WIS (w/w) fed-batch enzymatic hydrolysis, glucose yields at $96 \mathrm{~h}$ were 82 and $67 \%$ of the theoretical yield with initial enzyme loading and split enzyme addition, respectively, at the fixed ratio of 10 FPU (g WIS) ${ }^{-1}$ (Fig. 3d, e; Additional file 1: Table S1). This indicates that mixing is of utmost importance for the initial as well as for sustained hydrolytic activities, and that unproductive adsorption to e.g. lignin and enzyme degradation are no major issues in the present case. Recently, the present view of irreversible and unproductive adsorption of hydrolases to lignin has indeed been challenged [19].

The key for successful fed-batch hydrolysis is to find a balance between the addition and degradation of solids. To predict the hydrolysis progress so that overfeeding could be avoided, we re-fitted a previously developed hydrolysis model (Eq. 1-4) [9] to steam pre-treated wheat straw. 

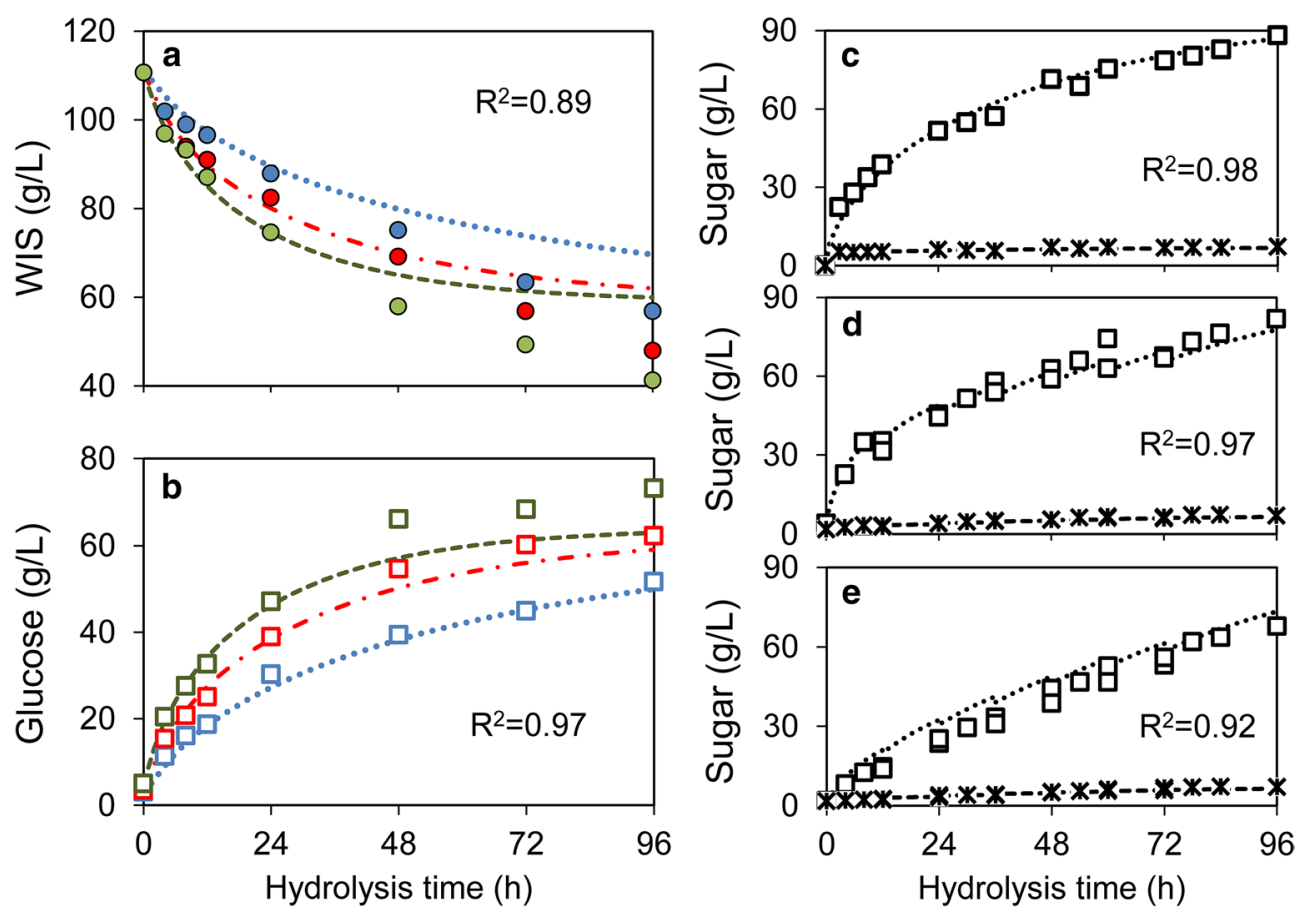

Fig. 3 Fitting and validation of enzymatic hydrolysis model. $\mathbf{a}$ and $\mathbf{b}$ Concentrations of residual WIS (a) and of glucose (b) after fitting the hydrolysis model to batch experiments at $10 \%$ (w/W) WIS using enzyme dosages of 5 (blue), 10 (red) and 15 (green) FPU (g WIS) ${ }^{-1}$. c-e Validation of the model was carried out by simulating the time course of glucose (squares and dotted lines) and xylose (stars and dashed lines) concentrations in a separate set of experiments using $15 \%$ WIS and 10 FPU (g WIS $)^{-1}$ in batch mode (c), fed-batch with all enzymes added initially (d) and fed-batch with enzymes added proportionally to substrate $(\mathbf{e})$. Simulations are illustrated in lines and experiments in symbols. The coefficients of regression $\left(R^{2}\right)$ are listed in each sub figure

$$
\begin{aligned}
& \frac{\mathrm{d} E_{\mathrm{ad}}}{\mathrm{dt}}=k_{\mathrm{ad}} \cdot\left(E_{\mathrm{eq}}-E_{\mathrm{ad}}\right)^{2}, \\
& E_{\mathrm{eq}}=E_{\mathrm{load}} \cdot \frac{S_{0}}{S}, \\
& r_{\text {hydrolysis }}=k \cdot \frac{E C \cdot S}{1+G / K_{\mathrm{G}}}=k \cdot \frac{E_{\mathrm{ad}} C}{1+G / K_{\mathrm{G}}}, \\
& r_{X_{\mathrm{n}}}=r_{C} \cdot \gamma .
\end{aligned}
$$

For nomenclature and optimized parameter values, see Table 1 . The model was fitted by minimizing the residuals between the estimated and measured enzyme adsorption and concentrations of residual WIS, glucose and xylose during the $10 \%$ (w/w) WIS batch hydrolysis (Fig. 3a, b). The fitted parameters (Table 1) were validated with a separate set of hydrolysis experiments, including $15 \%$ (w/w) WIS batch hydrolysis and $15 \%(\mathrm{w} / \mathrm{w})$ WIS fed-batch hydrolysis experiments (Fig. 3c-e). Because they are fitted and validated on varied experimental datasets, kinetic models represent a set of collected information of the substrates, enzyme and their interactions. The model used here was originally developed for hydrolysis of birch [9], was adapted here for wheat straw, and has recently also been adapted for hydrolysis of corn stover [20], showing the wide validity and applicability of the model.

The hydrolysis model was integrated into a modelbased control loop which was developed for determining the times and amounts of solid feedings that would enable good mixing while promoting rapid turnover of cellulose (Fig. 4). Basically, a sequence of $1 \mathrm{~h}$ batch processes were carried out in silico. At the end of each batch simulation, the extent of WIS solubilisation (assumed equal to the cellulose degradation) was checked. If a certain fraction $(\varphi)$ of the cellulose had been solubilized, a feeding event was triggered (Eq. 5). The amount of solids to be added was calculated based on the residual WIS and the mixing capacity of the reactors, expressed as an upper boundary for the WIS content in the reactor $\mathrm{WIS}_{\mathrm{UB}}$, empirically determined to be $12-13 \%(\mathrm{w} / \mathrm{w})$. Thus, at time $i$,

$$
\begin{gathered}
\text { if } \frac{C_{i-1}^{\prime}-C_{i}}{C_{i-1}^{\prime}}>\varphi \text {, then add solids corresponding to } \\
\mathrm{WIS}_{\mathrm{add}, i}=\frac{\mathrm{WIS}_{\mathrm{UB}} \cdot\left(w_{i}+w_{\mathrm{adds}}\right)-\mathrm{WIS}_{i}}{1-\mathrm{WIS}_{\mathrm{UB}} / \mathrm{WIS}_{\text {Solids }}}
\end{gathered}
$$


Table 1 Optimized parameters of the enzymatic hydrolysis and yeast fermentation

\begin{tabular}{|c|c|c|c|c|}
\hline Parameters & Optimized value & $95 \%$ Confidence intervals & Unit & Description \\
\hline$k_{\mathrm{ad}}$ & 0.27 & {$[0.03,0.5]$} & g solid FPU ${ }^{-1} h^{-1}$ & Adsorption rate constant \\
\hline k & 0.016 & {$[0.009,0.03]$} & g cellulose $\mathrm{FPU}^{-1} \mathrm{~h}^{-1}$ & Hydrolysis rate constant \\
\hline$K_{\mathrm{G}}$ & 6.13 & {$[2.7,13.8]$} & $\mathrm{gL}^{-1}$ & Inhibition constant of glucose in cellulose hydrolysis \\
\hline$\gamma$ & 0.028 & {$[0.01,0.08]$} & - & Proportionality factor between xylan and cellulose degradation \\
\hline$K_{\text {iEtOH }}$ & 16.6 & Assumed $^{\mathrm{a}}$ & $g L^{-1}$ & Inhibition constant of ethanol in cellulose hydrolysis \\
\hline$q_{\mathrm{G}}$ & 1.6 & Assumed $^{a}$ & $g g^{-1} h^{-1}$ & Specific glucose uptake rate by yeast \\
\hline K & 0.01 & Assumed $^{b}$ & $\mathrm{gL}^{-1}$ & Saturation constant of glucose uptake \\
\hline$Y_{\text {EtOH }}$ & 0.42 & Assumed $^{b}$ & $\mathrm{~g} \mathrm{~g}^{-1}$ & Ethanol yield on glucose \\
\hline$\alpha$ & 0.026 & Assumed $^{b}$ & $h^{-1}$ & $\begin{array}{l}\text { Pre-exponential factor of the ethanol-induced death rate coef- } \\
\text { ficient }\end{array}$ \\
\hline$\beta$ & 0.0037 & Assumed $^{b}$ & $\mathrm{Lg}^{-1}$ & $\begin{array}{l}\text { Exponential factor of the ethanol-induced death rate coef- } \\
\text { ficient }\end{array}$ \\
\hline
\end{tabular}

a Modified from [9]

b Modified from [29]

where $C_{i}$ is the residual amount of cellulose (g) at time $i, C_{i-1}^{\prime}$ is the total amount of cellulose after the previous addition including the residual amount from the preceding time frame $(\mathrm{g}), w_{i}$ is the total weight before the new addition $(\mathrm{g}), w_{\text {adds }}$ is the increased weight by feedings other than solid substrates at time $i(\mathrm{~g}), \mathrm{WIS}_{i}$ is the insoluble solids in the bioreactor at time $i$ before the new addition (g) and WIS Solids is the WIS content in the solid fraction of the slurry $(\% \mathrm{w} / \mathrm{w})$. Changes in volume and concentrations due to the feed event were immediately incorporated in the relevant variables and a new batch simulation was started from the updated initial values (Fig. 4).

The parameter $\varphi$ at the check point determines the feeding frequency and the time frame of the overall process. A feeding profile based on low cellulose conversion, e.g. $\varphi=30 \%$, resulted in more frequent additions and consequently a possibility to reach higher cumulative WIS addition. However, the intense labour demands required by such a feeding plan could be impractical and may be unnecessary. With frequent additions, the apparent viscosity of the SSCF broth would be kept high and thus more power input for mixing would be required. In contrast, starting the feed of solids at higher degree of cellulose conversion would ensure sufficient mixing, but would prolong the process time needed to reach the same total WIS addition. After simulation and experimental tests, feeding upon $60 \%$ cellulose degradation $(\varphi=60 \%)$ was chosen since it gave desirable WIS addition with reasonable work load. Fed-batch hydrolysis carried out according to model predictions using these parameters worked smoothly and no mixing problems were encountered.

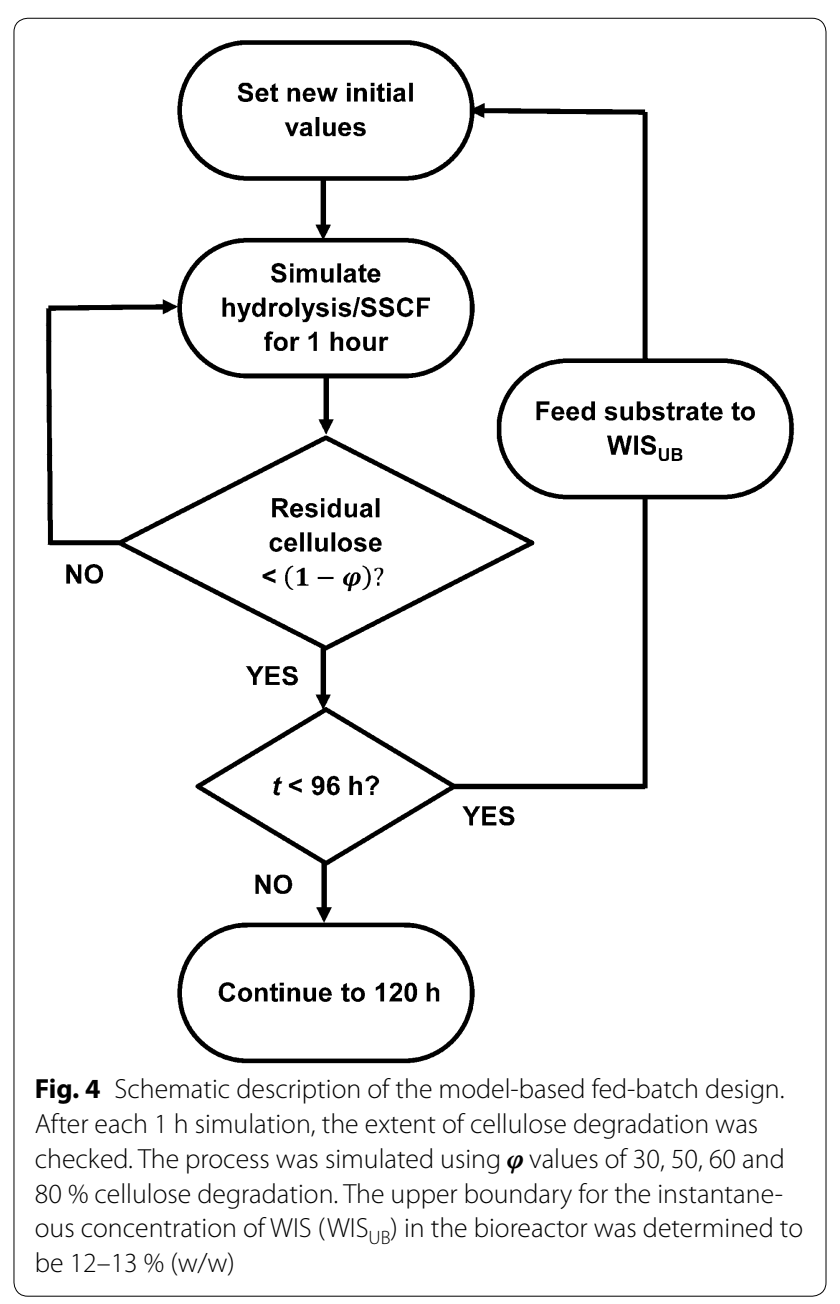


In conclusion, adding all enzymes initially accelerates the liquefaction of the medium. The rapidly reduced viscosity in the early stages of the process resulted in better mixing throughout the whole process. Furthermore, feeding of solids according to the predicted extent of hydrolysis enabled a balance between process time and the overall substrate addition, while reducing the risk of overfeeding.

\section{Model-based feeding of solids and addition of yeast resulted in the most productive SSCF at high solid loading} In the SSCF set up, glucose and xylose released during hydrolysis are taken up by yeast cells and converted to ethanol. We investigated how the process performance was affected by feeding of not only solids, but also of enzymes and yeast cells. Experimental results are summarized in Additional file 2: Table S2.

\section{Enzyme feeding in SSCF}

Enzyme feeding has previously been shown to improve the overall performance of SSCF due to enhanced xylose utilization, by limiting the glucose release and maintaining a favourable xylose to glucose ratio during the process $[2,10]$. However, according to our results at high solid loading of wheat straw, the appropriate enzyme feeding mode appears to be adding all enzymes at the start in order to accelerate liquefaction of the medium. With all enzymes added initially in the SSCF, ethanol production was boosted in the early phase and final concentrations were higher compared to SSCF with enzyme feed; for example, the ethanol yield on total sugars at $96 \mathrm{~h}$ increased from 77.8 to $81.5 \%$ of the theoretical yield in $15 \%(\mathrm{w} / \mathrm{w})$ WIS fed-batch SSCF (Additional file 2: Table S2).

To enable its use in the SSCF context, the hydrolysis model was extended to include ethanol inhibition of enzymatic hydrolysis (Eq. 6), glucose consumption $\left(r_{\mathrm{G}, \mathrm{cons}}, \mathrm{Eq} .7\right)$, ethanol production $\left(r_{\mathrm{EtOH}}\right.$, Eq. 8$)$ and ethanol-induced cell death $\left(r_{d}\right.$, Eq. 9$)$ to represent the main reactions involved in an SSCF which could affect the hydrolysis process (for nomenclature and parameter values, see Table 1).

$$
\begin{aligned}
& r_{\mathrm{G}, \mathrm{prod}}=\frac{r_{\text {hydrolysis }}}{1+\mathrm{EtOH} / K_{i \mathrm{EtOH}}}, \\
& r_{\mathrm{G}, \mathrm{cons}}=\frac{q_{G} \cdot G}{K+G} \cdot X, \\
& r_{\mathrm{EtOH}}=r_{\mathrm{G}, \mathrm{cons}} \cdot Y_{\mathrm{EtOH}}, \\
& r_{\mathrm{d}}=\alpha \cdot e^{\beta \cdot \mathrm{EtOH}} \cdot X .
\end{aligned}
$$

The resulting model was integrated into the process design loop to determine the amounts and times for solid feeds (Fig. 4). Since inhibition of enzyme by glucose was weaker, the hydrolysis was faster and solid feeds were scheduled earlier in the SSCF compared to those in the separate hydrolysis process. SSCF experiments with substrate feeding based on the model prediction were carried out in both laboratory and demonstration scales. $22 \%(\mathrm{w} / \mathrm{w})$ overall WIS addition was achieved without mixing problem throughout the process (Figs. 5, 6).

\section{Yeast cell feeding in SSCF}

A sufficient inoculum size for an SSCF process implies that the amount of cells added is enough to consume

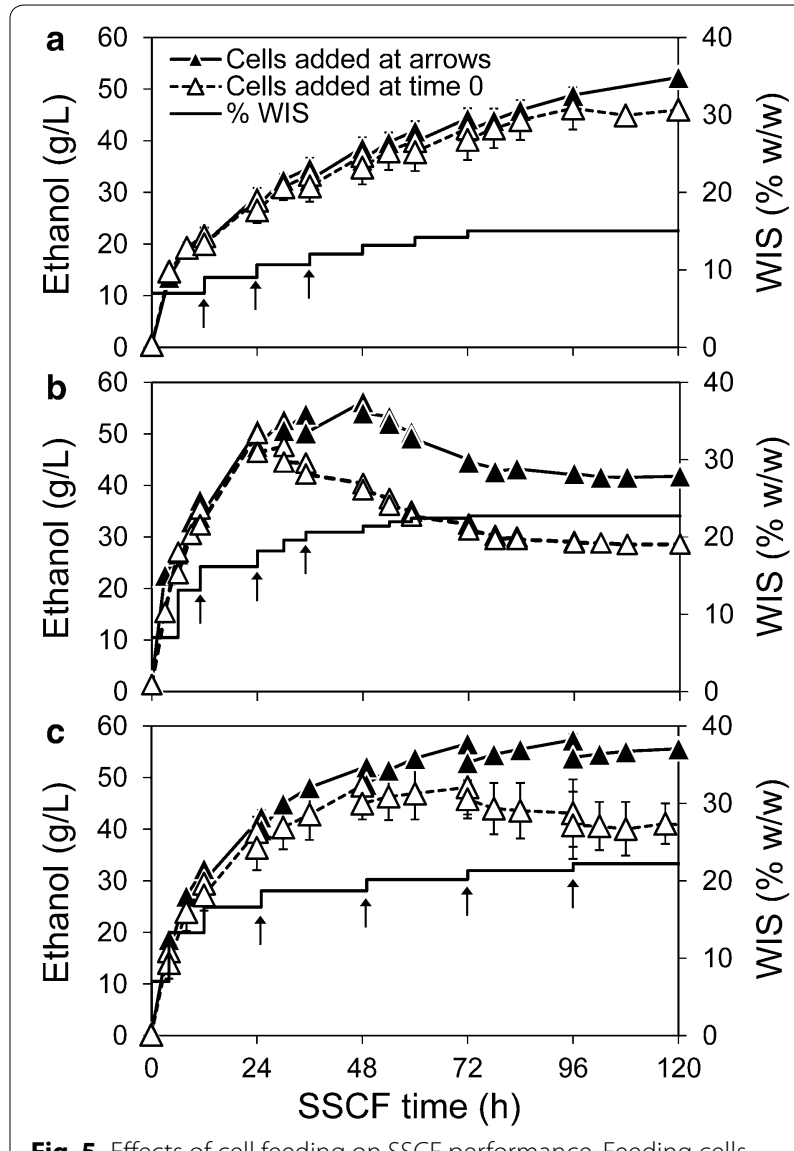

Fig. 5 Effects of cell feeding on SSCF performance. Feeding cells improved the overall performance of fed-batch SSCF process (filled triangles) compared to loading all cells initially at $0 \mathrm{~h}$ (open triangles), in $15 \%(w / w)$ final accumulated WIS addition (a), $22 \%(w / w)$ final WIS with unoptimized addition of solids and insufficient mixing after $24 \mathrm{~h}$ (b), and $22 \%(\mathrm{w} / \mathrm{w})$ final WIS with optimized addition of solids and efficient mixing (c). At high accumulated WIS concentration, stress induced by inhibitors and ethanol is more severe than at low WIS contents. Consequently, the benefit of feeding cells instead of adding them all initially was clearer. The arrows indicate addition of yeast cells in the experiments represented with filled triangles. The error bars indicate standard deviation of duplicate experiments 


\section{a}

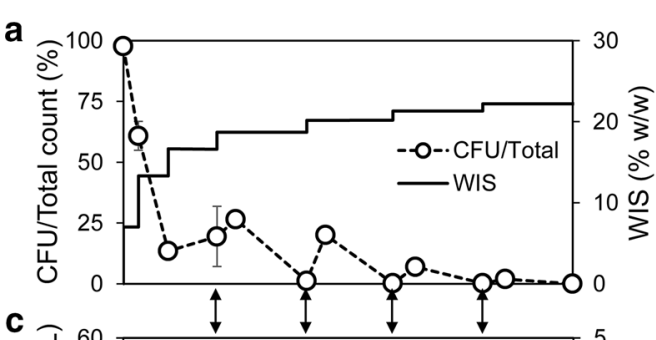

C

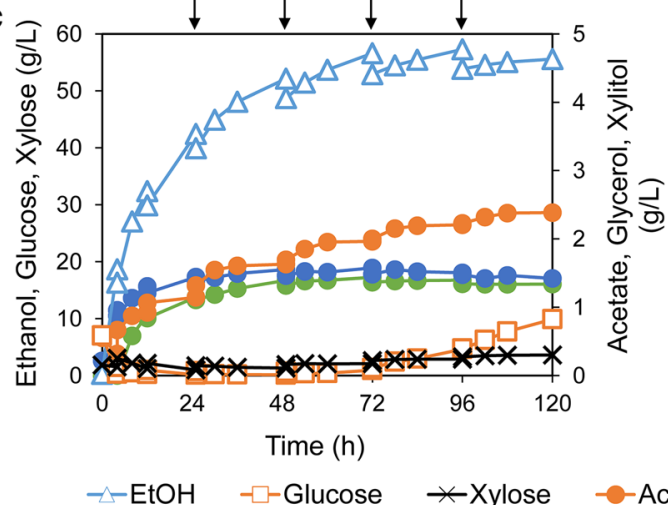

b

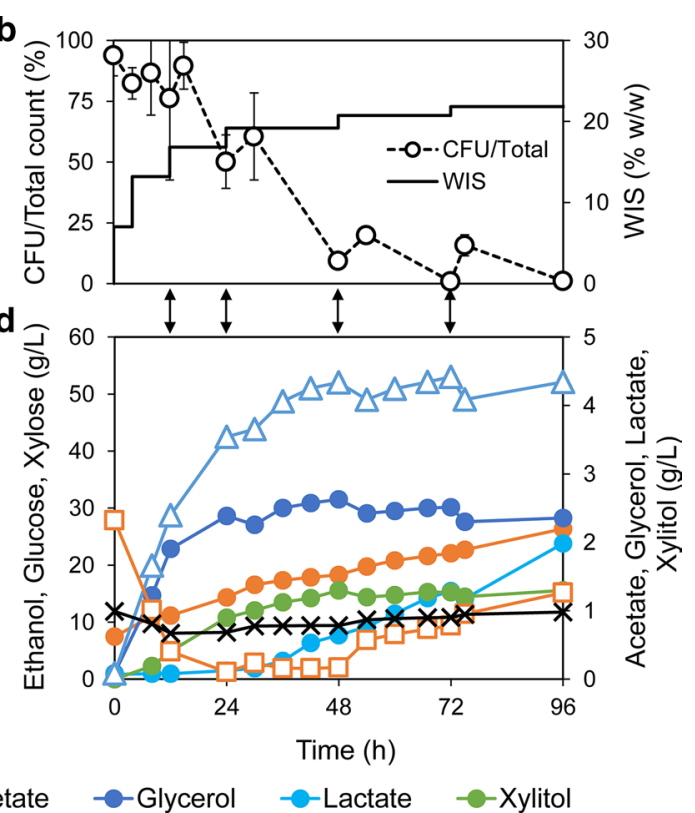

Fig. 6 Comparison of lab and demo-scale SSCF. Time courses of cell viability, cumulative WIS addition, concentrations of sugars, ethanol and major by-products of multi-feed SSCF in lab scale $(\mathbf{a}, \mathbf{c})$ and in demo plant $(\mathbf{b}, \mathbf{d})$. The changes in WIS content indicate addition of solids, and the arrows between the panels indicate addition of yeast cells. Concentrations in $C$ and $D$ are averages from two biological replicates. Most data points showed deviation below $5 \%$ between duplicate experiments. Error bars in $\mathbf{a}$ and $\mathbf{b}$ are standard deviations in duplicate experiments. Furfural and 5-hydroxymethyl furfural concentrations were below 0.5 and $0.2 \mathrm{~g} \mathrm{~L}^{-1}$ in the lab case, and below 0.1 and $0.05 \mathrm{~g} \mathrm{~L}^{-1}$ in the demo case

glucose at the rate of release, given the inhibitor concentrations in the medium. Selection of the appropriate inoculum size was carried out in shake flask batch SSCF with $20 \%(\mathrm{w} / \mathrm{w})$ WIS and 10 FPU (g WIS $)^{-1}$ enzyme with $2 \mathrm{~h}$ pre-hydrolysis to enable mixing. Batch SSCF is more challenging for cells than fed-batch because all inhibitors are present at the beginning of the batch. After $2 \mathrm{~h}$ prehydrolysis, inocula equivalent to $0.01,0.02$ and $0.04 \mathrm{~g}$ cell dry weight (DW) $(\mathrm{g} \text { WIS })^{-1}$ were added. Increased ethanol production by $12 \%\left(37.7-42.2 \mathrm{~g} \mathrm{~L}^{-1}\right)$ after $24 \mathrm{~h}$ incubation was obtained when the cell loading was increased from 0.01 to 0.02 . When the inoculum size was further increased to $0.04 \mathrm{~g}(\mathrm{~g} \mathrm{WIS})^{-1}$, no improvement in ethanol production was observed. The results suggested that at such WIS and enzyme dosage, $0.02 \mathrm{~g}(\mathrm{~g} \text { WIS })^{-1}$ cell loading was sufficient to consume available sugars while handling high level of inhibitors. Thus, $0.02 \mathrm{~g} \mathrm{DW}$ (g WIS) ${ }^{-1}$ were used in all SSCF experiments.

The amount of viable yeast cells, measured by colony forming assay, has been found to correlate with the ethanol production during SSF/SSCF of pre-treated birch, spruce and wheat straw, and the viability, estimated as colony forming units (CFU) per total cell count, often decreases during $\mathrm{SS}(\mathrm{C}) \mathrm{F}$ at high gravity $[9,10,15,21]$. Feeding cells, in other words, split inoculation, has been shown to effectively improve the viability of the population as well as the ethanol production in $20 \%(\mathrm{w} / \mathrm{w})$ WIS
SS(C)F on birch, spruce and corn stover [9, 10, 20]. In this work, the effects of cell feeding on SSCF were examined under varied solid feeding schemes. At the intermediate WIS addition of $15 \%$ (w/w), feeding cells showed small effects on the process but slightly increased the final ethanol titre (Fig. 5a), likely due to that yeast metabolism was not completely eliminated by the inhibitors and the produced ethanol at this WIS level. In cases of an overfed $22 \%(\mathrm{w} / \mathrm{w})$ WIS SSCF, where proper mixing could not be maintained, cell feeding to some extent salvaged the process and resulted in continued ethanol production (Fig. 5b). In the model-based $22 \%$ (w/w) WIS SSCF, where mixing was maintained throughout the process, cell feeding also led to maintained fermentation and final ethanol concentrations of more than $55 \mathrm{~g} \mathrm{~L}^{-1}$. In contrast, fermentation ceased above ethanol concentrations of $45-50 \mathrm{~g} \mathrm{~L}^{-1}$ in SSCF with initial cell inoculation (Fig. 5c).

Thus, our results explicitly pointed out that it is more beneficial to feed cells at the later stage of SSCF, when the ethanol concentration is high and viability is low. In this case, feeding of continuously propagated cells maintained the fermentation activity and further improved ethanol yields. Feeding cells at lower ethanol level (roughly below $45 \mathrm{~g} \mathrm{~L}^{-1}$ ) made little difference in final ethanol titres (Fig. 5). If higher ethanol titre is the target and thus continuation of fermentation is required, addition of cells 
is a simple and effective way to maintain sufficient cell viability.

Taken together, by extending fed-batch SSCF to include feeds of not only solid substrate, but also cells and in some cases enzymes, it is possible to achieve balanced rates of substrate feeding and hydrolysis, sugar release and uptake, ethanol production and cell viability. The model-based process design presented here provides a versatile working platform for high gravity lignocellulosebased processes.

\section{Scale-up of lab-optimized Multi-feed SSCF process to demo scale gave similar results as in lab}

The lab-optimized multi-feed SSCF and yeast cultivation processes were carried out in $10 \mathrm{~m}^{3}$ scale at the SP Biorefinery Demo Plant in Örnsköldsvik, Sweden, after adaptation to the plant's capabilities (see operating conditions in Table 2). A new batch of pre-treated raw material had to be produced, and despite identical operating set points the new pre-treated slurry differed from the one used in the lab experiments in terms of sugar composition and inhibitor concentrations (Table 3).

The time courses of cell viability, cumulative WIS addition, major sugars, ethanol and by-products are

Table 2 Comparison of the lab-scale 'best' performing SSCF and accordingly designed demo-scale SSCF

\begin{tabular}{lll}
\hline & Lab & Demo plant \\
\hline Total weight & $1252 \mathrm{~g}$ & $5481 / 5583 \mathrm{~kg}^{\mathrm{a}}$ \\
WIS loading $(\% \mathrm{w} / \mathrm{w})$ & 22.2 & $21.9 / 21.5^{\mathrm{a}}$ \\
Pre-treatment liquor & 0 & $178 / 196 \mathrm{~kg}^{\mathrm{a}}$ \\
Operating time & $120 \mathrm{~h}$ & $96 \mathrm{~h}$ \\
Cells added at & $0,24,48,72$ and $96 \mathrm{~h}$ & $0,12,24,48$ and $72 \mathrm{~h}$ \\
Solids added at & $0,4,12,24,48,72$ and & $0,4,12,24,48$ and $72 \mathrm{~h}$ \\
& $96 \mathrm{~h}$ &
\end{tabular}

a The actual operation data for duplicate experiments

Table 3 Compositions of the two batches of pre-treated wheat straw used in lab and demo plant

\begin{tabular}{|c|c|c|c|c|c|}
\hline \multicolumn{3}{|c|}{$\begin{array}{l}\text { Contents in solid phase } \\
\left(\% \mathrm{~g}(\mathrm{~g} \text { WIS })^{-1}\right)\end{array}$} & \multicolumn{3}{|c|}{ Contents in liquid phase $\left(\mathrm{g} \mathrm{L}^{-1}\right)$} \\
\hline & Lab & Demo & & Lab & Demo \\
\hline Glucan & 47.9 & 42.4 & Glucose & 6.8 & 2.4 \\
\hline Xylan & 2.3 & 2.6 & Xylose & 12.8 & 18.3 \\
\hline Mannan & 0.2 & 0.2 & Mannose & 0.4 & 0.4 \\
\hline Galactan & 0.04 & 0.0 & Galactose & 1.0 & 0.8 \\
\hline \multirow[t]{4}{*}{ Arabinan } & 0.1 & 0.08 & Arabinose & 2.0 & 2.8 \\
\hline & & & Acetic acid & 3.8 & 3.2 \\
\hline & & & Furfural & 4.0 & 0.8 \\
\hline & & & 5-Hydroxymethylfurfural & 1.4 & 0.4 \\
\hline
\end{tabular}

compared with lab-scale results in Fig. 6. Despite the differences in substrate and scale, the multi-feed SSCF performed similarly overall in the two cases. In the first $48 \mathrm{~h}$, the cell viability was higher in the demo-scale experiments because of the lower inhibitor concentrations in the pre-treatment liquor. Due to slower cell separation, the initial cell addition at $0 \mathrm{~h}$ was lower in the demo than in the lab experiments. Fresh cells were instead added already after $12 \mathrm{~h}$, which also boosted the viability. In lab experiments, the ethanol concentration reached $57.3 \mathrm{~g} \mathrm{~L}^{-1}$ and the yield on total sugar was $66 \%$ of the theoretical at $96 \mathrm{~h}$ (Fig. 6a, c). No mixing issue was observed throughout the process. In the demo trials, the ethanol concentration peaked at $53.0 \mathrm{~g} \mathrm{~L}^{-1}$ at $72 \mathrm{~h}$, and the final yield on total sugar at $96 \mathrm{~h}$ was $54 \%$ of the theoretical (Fig. 6b, d). The results were quite reproducible in the demo scale, with less than $5 \%$ deviation between the two repeated experiments.

Large-scale operation is complicated and unexpected issues can happen. Therefore a process going for large scale must be robust and resistant to mistakes and deviations in operations. In fuel ethanol production, contamination is difficult to eliminate since the process is usually carried out under non-sterile conditions [22]. The fedbatch strategy used in both yeast propagation and SSCF processes kept the sugar level low and therefore made it more difficult for bacteria to take over. Increasing the use of inhibitory pre-treatment liquor during both yeast propagation and SSCF could further repress bacterial growth, however, this must be weighed against the potential negative effects on the ethanol fermentation.

In this context, multi-feed SSCF is a flexible process which balances substrate input, saccharification and fermentation, by allowing adjustment of the feed rates according to the circumstances during a run. In the demo trials, we noticed that feeding solids to the SSCF and separation of yeast from the propagation medium were two time-consuming steps. For feasible application of the multi-feed strategy in large scale, use of automated and continuous solid feeding, and more powerful cell separation or use of flocculent yeast to facilitate separation of cells from the propagation medium should be considered [23]. Despite these issues, the process was quite robust and lab-scale results were reproduced in the demo scale.

\section{Development of multi-feed SSCF on varied raw materials showed the important factors for high ethanol titre}

The strategy of combining substrate, enzyme and yeast feed in $\mathrm{SS}(\mathrm{C}) \mathrm{F}$ has been developed and tested on pretreated birch [9] and spruce [10], and was further developed on wheat straw in this work. On birch, multifeed SSCF did not give high ethanol titres, but clearly improved the reproducibility [9]. One clear reason for 
the low product concentration was that the birch pretreatment liquor contained quite high inhibitor concentrations, like $18.3 \mathrm{~g} \mathrm{~L}^{-1}$ acetic acid and $3.7 \mathrm{~g} \mathrm{~L}^{-1}$ furfural. Therefore, with increasing overall substrate loads, the ethanol titres actually decreased. On spruce, feeding of enzymes actually increased the ethanol titre when combined with feeds of yeast and solids. By using $50 \%$ (v/v) spruce pre-treatment liquor in the cell propagation and a very frequent manual substrate addition (every 4 or $8 \mathrm{~h}$ ), relatively high ethanol titres of $40 \mathrm{~g} \mathrm{~L}^{-1}$ were achieved in a $20 \%(\mathrm{w} / \mathrm{w})$ WIS process [10]. In the current work on steam pre-treated wheat straw, loading all enzyme at beginning of the process clearly boosted both the enzymatic hydrolysis and the SSCF, and high final concentrations of ethanol were achieved. The high level of ethanol became challenging for the yeast when combined with other inhibitors. Therefore, the effect of the yeast feed was to maintain the fermentation at the later stages of the SSCF rather than boosting it in the early stages.

The different results obtained in these studies are in part due to the different nature of the raw materials, i.e. hardwood, softwood and agricultural residues, respectively. The differences are also an outcome of a maturation process of the multi-feed concept. In this work, planning of the substrate feeds according to model prediction reduced the feeding frequency. This required less labour in manual operations, but still resulted in higher overall WIS within a similar time frame. Moreover, in this study, the procedures for cell propagation were well established and integrated with the process. We used a mixture of molasses and pre-treatment liquor for providing sugars and adaptation pressure during cell propagation. The semi-continuous cultivation delivered cells with stable viability and fermentation capacity. The multi-feed process was practical for scaling-up and delivered similar results in $10 \mathrm{~m}^{3}$ scale as in the lab. The final yield on total sugars must be further improved, which will lead to even higher final ethanol titres. We also found that the ethanol concentration peaked before the last substrate addition. Therefore an alternative process setup would be to skip the last two substrate additions. In conclusion, the multifeed SSCF process presented here represents a complete routine for establishing a high gravity, i.e. high solids content, production workflow from pre-treated lignocellulose to value-added products (Fig. 1).

\section{Conclusions}

We have demonstrated a dynamic approach to process development, using kinetic modelling to predict the feeding of solids and the outcomes of such feedings. With the model-based feeding profiles, it is possible to reach a high-WIS content of $22 \%(\mathrm{w} / \mathrm{w})$ without mixing issues in a standard bioreactor, resulting in high ethanol concentrations $\left(57.3 \mathrm{~g} \mathrm{~L}^{-1}\right)$ from pre-treated wheat straw. For obtaining a successful multi-feed SSCF process, adding all enzymes at the beginning is a key factor for high titre and productivity. This is also beneficial for the economic and environmental impact of the process since the enzyme requirement can be reduced. Feeding yeast is effective for maintaining the viability and fermentation activity. The systematic optimization reported in this work represents a robust and reproducible routine for development of other lignocellulosebased process.

\section{Methods}

\section{Raw material}

Pre-treated wheat straw used throughout this study was provided by SP Biorefinery Demo Plant (Örnsköldsvik, Sweden). The wheat straw was steam pre-treated with $1 \%(\mathrm{w} / \mathrm{v}) \mathrm{H}_{2} \mathrm{SO}_{4}$. The biomass slurry after pre-treatment was separated by filtration into a water-insoluble solid (WIS) fraction and a liquid hydrolysate fraction, here called pre-treatment liquor. The solid fraction was used for hydrolysis and SSCF experiment, while the pre-treatment liquor was used for seed cultivation (Table 3). The sugar composition in the solid fraction was determined according to the NREL protocol TP-510-42618 [24]. The sugar and inhibitor composition of pre-treatment liquor was determined by IC and HPLC measurement, respectively. WIS content for the pre-treated biomass was determined by weighing an aliquot of the solid fraction, thorough washing with deionized water and weighing after $24 \mathrm{~h}$ drying at $105^{\circ} \mathrm{C}$. Enzyme activity in filter paper units (FPU) was determined according to the NREL protocol TP-510-42628 [25] with reduced reaction volume [26].

\section{Strain and media}

The recombinant and evolutionary engineered strain of S. cerevisiae KE6-12.A [27] capable of fermenting glucose and xylose was used in all SSCF experiments. The strain was maintained as a frozen glycerol stock. Prior to use, the strain from frozen stock was streaked on a fresh YPD agar plate containing $10 \mathrm{~g} \mathrm{~L}^{-1}$ yeast extract, $20 \mathrm{~g} \mathrm{~L}^{-1}$ peptone, $20 \mathrm{~g} \mathrm{~L}^{-1}$ agar and $20 \mathrm{~g} \mathrm{~L}^{-1}$ glucose. The media used for all hydrolysis and SSCF experiments contained pre-treated wheat straw, $0.5 \mathrm{~g} \mathrm{~L}^{-1}\left(\mathrm{NH}_{4}\right)_{2} \mathrm{HPO}_{4}$ and 125 $\mu \mathrm{L} \mathrm{L}^{-1}$ of Vitahop (BetaTech $\mathrm{GmbH}$, Schwabach, Germany) to reduce the risk of contamination. The $\mathrm{pH}$ of the media was adjusted to 5.0 with $3 \mathrm{M} \mathrm{NaOH}$. All enzyme hydrolysis, seed cultivation and SSCF experiments were carried out in 3.6 L Labfors bioreactors (INFORS HT, Bottmingen-Basel, Switzerland) unless otherwise stated. The bioreactors were autoclaved at $121{ }^{\circ} \mathrm{C}$ for $20 \mathrm{~min}$ prior to the experiments. 


\section{Enzymatic hydrolysis}

Cellic CTec II enzymes (Novozymes, Denmark) were used in this work. Batch and fed-batch hydrolysis were conducted with final accumulated WIS of 15-21\% (w/w, dry basis). For enzyme dosage optimization experiment, enzyme loading was varied at 5, 10 and 15 FPU ( $(\mathrm{g} \mathrm{WIS})^{-1}$. The hydrolysis conditions were temperature at $35{ }^{\circ} \mathrm{C}, \mathrm{pH}$ controlled at 5 with $3 \mathrm{M} \mathrm{NaOH}$ and agitation rate at $400 \mathrm{rpm}$. The hydrolysis was initiated by adding enzyme preparations to the bioreactor. Fedbatch was carried out by feeding solid and/or enzyme according to the designed feed profiles. Samples for WIS, free enzyme and sugar analysis were taken every 6 or $12 \mathrm{~h}$.

\section{Aerobic batch and fed-batch seed cultivation}

Yeast cells used in SSCF were produced in aerobic batch followed by fed-batch culture using wheat straw pre-treatment liquor to allow cells to adapt to the used medium. Inoculum culture was grown in liquid YPD medium in a $250-\mathrm{mL}$ Erlenmeyer flask at $30{ }^{\circ} \mathrm{C}$ at a shaker speed of $200 \mathrm{rpm}$ for $24 \mathrm{~h}$. The culture was initiated by inoculating the YPD culture at $10 \%(\mathrm{v} / \mathrm{v})$ to the batch. The composition of the batch medium was $10 \%$ $(\mathrm{v} / \mathrm{v})$ molasses, pre-treatment liquor at various amounts as indicated below, $7.5 \mathrm{~g} \mathrm{~L}^{-1}\left(\mathrm{NH}_{4}\right)_{2} \mathrm{SO}_{4}, 3.5 \mathrm{~g} \mathrm{~L}^{-1}$ $\mathrm{KH}_{2} \mathrm{PO}_{4}, 0.7 \mathrm{~g} \mathrm{~L}^{-1} \mathrm{MgSO}_{4} \cdot 7 \mathrm{H}_{2} \mathrm{O}, 2 \mathrm{~mL} \mathrm{~L}^{-1}$ trace metals and $1 \mathrm{~mL} \mathrm{~L}^{-1}$ vitamins. The trace metal and vitamin solutions were prepared according to [28]. Glucose and xylose were added to obtain initial concentrations of $20 \mathrm{~g} \mathrm{~L}^{-1}$. Pre-treatment liquor was added to the batch media at $0,10,20,30,50$ and $75 \%(\mathrm{v} / \mathrm{v})$. The batch phase was carried out for $24 \mathrm{~h}$ followed by fed-batch cultivation. The fed-batch phase was commenced by adding feed media at the specified dilution rate. Two dilution rates of 0.05 and $0.075 \mathrm{~h}^{-1}$ were tested. Different feed media were tested with the following compositions: $2 \mathrm{~L}$ of $50 \%(\mathrm{v} / \mathrm{v})$ pre-treatment liquor, $2 \mathrm{~L}$ of $80 \%(\mathrm{v} / \mathrm{v})$ pretreatment liquor and $1 \mathrm{~L}$ of $50 \%(\mathrm{v} / \mathrm{v})$ pre-treatment liquor followed by $1 \mathrm{~L}$ of $80 \%(\mathrm{v} / \mathrm{v})$ pre-treatment liquor. The feed media contained the same levels of molasses and salts as the batch media. Batch and fed-batch cultivations were performed at $30{ }^{\circ} \mathrm{C}$ and $\mathrm{pH}$ was maintained at 5 by addition of $3 \mathrm{M} \mathrm{NaOH}$. Aeration was maintained at $1 \mathrm{~L} \mathrm{~min}^{-1}$ during batch and at $2 \mathrm{~L} \mathrm{~min}^{-1}$ during fedbatch. The stirrer speed was kept at $400 \mathrm{rpm}$ during batch and at $800 \mathrm{rpm}$ during fed-batch. Dissolved oxygen stayed above $20 \%$ of air saturation throughout the cultivation. Cells were harvested by centrifugation at $5100 \mathrm{rpm}$ for $5 \mathrm{~min}$. The cell pellets were washed and re-suspended in $0.9 \%(\mathrm{w} / \mathrm{v}) \mathrm{NaCl}$ solution before being used for SSCF fermentation.

\section{SSCF in shake flasks}

Batch shake flask SSCF was carried out in a $250 \mathrm{~mL}$ baffled Erlenmeyer flask containing pre-treated wheat straw at $20 \%(\mathrm{w} / \mathrm{w})$ WIS content. The $\mathrm{pH}$ was initially adjusted to 5 using $3 \mathrm{M} \mathrm{NaOH}$. Before inoculation, $2 \mathrm{~h}$ pre-hydrolysis at $50{ }^{\circ} \mathrm{C}$ was performed to partially solubilize the solid and facilitate mixing. SSCF was initiated by addition of various amounts of yeast cells equivalent to 0.01 , 0.02 and $0.04 \mathrm{~g}(\mathrm{~g} \mathrm{WIS})^{-1}$. The SSCF was conducted at $35^{\circ} \mathrm{C}$, with agitation rate at $180 \mathrm{rpm}$ with no $\mathrm{pH}$ control during the cultivation. Samples were taken every $24 \mathrm{~h}$ for cell, sugars and ethanol measurement.

\section{SSCF in bioreactors}

$10 \mathrm{FPU}$ (g WIS $)^{-1}$ enzyme loading and yeast cell ratio of $0.02 \mathrm{~g}(\mathrm{~g} \mathrm{WIS})^{-1}$ were used in bioreactor SSCF experiments. Fed-batch SSCF experiments were started with initial WIS of $7 \%(\mathrm{w} / \mathrm{w})$ and were fed to the final WIS content, with co-feeding of enzymes and/or yeast cells. When enzyme feeding was applied, enzyme preparations equivalent to $10 \mathrm{FPU}$ ( $\mathrm{g}$ added WIS) ${ }^{-1}$ were added to the bioreactor at each feeding. In cases with cells feedings, cells equivalent to $0.02 \mathrm{~g}$ (g added WIS) ${ }^{-1}$ were added to the bioreactor at each feeding. To keep the working volume the same under different feeding schemes, water equal to the amount of enzyme or cell solution added was used for the experiment with no cell and/or enzyme feeding. Samples were collected and analysed for sugars, fermentation products, residual inhibitors and cell concentrations. The process was conducted at $35{ }^{\circ} \mathrm{C}$, with agitation rate at $400 \mathrm{rpm}$ and $\mathrm{pH}$ at 5 by addition of $3 \mathrm{M}$ $\mathrm{NaOH}$.

\section{Multi-feed SSCF in demo plant}

At SP Biorefinery Demo Plant, the lab-optimized multifeed SSCF and yeast cultivation were carried out in large reactors $\left(10 \mathrm{~m}^{3}\right)$. A new batch of wheat straw was pretreated to obtain sufficient materials for the experiments (Table 3). The operating parameters for yeast cultivation and SSCF were basically the same as those optimized in the lab, but some modifications were made to fit the facilities in the plant. For yeast cultivation, a 300-L bioreactor was used to grow cells before the major cultivation in a $10-\mathrm{m}^{3}$ bioreactor. The numbers of yeast cells and bacteria in all cultivation steps were regularly monitored to follow yeast growth and risk of contamination. A continuous centrifuge with working capacity of $300 \mathrm{~L} \mathrm{~h}^{-1}$ was used to prepare concentrated cell slurry for SSCF. Before the start of the SSCF, a gentle pre-hydrolysis was initiated to facilitate mixing. During the SSCF, 450-600 kg of pre-treated solids were added from the top of the bioreactor at every feeding point. It took several hours until 
all the solids were mixed with the SSCF broth after each addition.

\section{Analytical procedures Cell concentration}

Cell concentration was measured by cell dry weight during the aerobic seed cultivation. The samples were centrifuged at $5100 \mathrm{rpm}$ for $5 \mathrm{~min}$ and the supernatants were discarded. The cell pellets were washed with deionized water, filtered through a pre-weighed $0.2 \mu \mathrm{m}$ filter paper (PESU-membrane), dried at $105^{\circ} \mathrm{C}$ for $24 \mathrm{~h}$ and subsequently weighed. During SSCF cultivation, the concentration of viable cells was measured by manual counting of colony forming units (CFU). CFU counts were obtained by plating $0.1 \mathrm{~mL}$ of sample on an YPD plate, after appropriate serial dilution. Total cell concentration was measured by counting cells under microscope using a counting chamber. Optical Density (OD) was measured by absorbance at $600 \mathrm{~nm}$ after appropriate dilution and zeroing using filtered liquid medium.

\section{Analysis of sugars, fermentation products and inhibitors}

Hydrolysis and fermentation samples were centrifuged at $5100 \mathrm{rpm}$ for $5 \mathrm{~min}$. The supernatant was collected and filtered using a $0.2-\mu \mathrm{m}$ filter. Samples were stored at $-20{ }^{\circ} \mathrm{C}$ prior to analysis. Concentrations of monomeric sugars (glucose, xylose, arabinose, galactose and mannose) were analysed on a high performance anion exchange chromatography system (ICS 3000, Dionex) with Dionex CarboPac PA1 guard and analytical columns (Thermo Scientific), and pulsed amperometric detection. Milli-Q water was used for sample elution at a flow rate of $1 \mathrm{ml} / \mathrm{min}$, and $300 \mathrm{mM} \mathrm{NaOH}$ was added at a flow rate of $0.5 \mathrm{ml} / \mathrm{min}$ before the detector. The column was regenerated between sample injections using a mixed eluent consisting of $20 \%$ Milli-Q water, $40 \% 300 \mathrm{mM} \mathrm{NaOH}$ and $40 \% 100 \mathrm{mM} \mathrm{NaOH}+85 \mathrm{mM}$ sodium acetate, followed by equilibration with Milli-Q water. Concentrations of fermentation products (glycerol, xylitol and ethanol) and inhibitors (acetic acid, 5-hydroxymethylfurfural and furfural) were determined on an UltiMate 3000 HPLC system with a Variable Wavelength absorbance detector set at $210 \mathrm{~nm}$ (Dionex) and an IR-101 refractive index detector (Shodex), using a Phenomenex Rezex ROA column. Samples were eluted at $80{ }^{\circ} \mathrm{C}$ using $0.8 \mathrm{ml} /$ $\min 5 \mathrm{mM} \mathrm{H}_{2} \mathrm{SO}_{4}$. The concentrations were calculated from calibration curves for standard solutions.

\section{Fermentation capacity test}

$1 \mathrm{~mL}$ cell sample was collected after the end of batch and fed-batch seed cultivation. The cell sample was washed once with deionized water before being inoculated into $5 \mathrm{ml}$ culture medium containing $10 \%(\mathrm{v} / \mathrm{v})$ pre-treatment liquor, $7.5 \mathrm{~g} \mathrm{~L}^{-1}(\mathrm{NH} 4)_{2} \mathrm{SO}_{4}, 3.5 \mathrm{~g} \mathrm{~L}^{-1} \mathrm{KH}_{2} \mathrm{PO}_{4}, 0.7 \mathrm{~g} \mathrm{~L}^{-1}$ $\mathrm{MgSO}_{4} \cdot 7 \mathrm{H}_{2} \mathrm{O}$. The culture was incubated at $30{ }^{\circ} \mathrm{C}$ with a shaking rate of $200 \mathrm{rpm}$ for $2 \mathrm{~h}$. Supernatant samples from the culture were collected for sugars and ethanol analysis.

\section{Yield and rate calculations}

Hydrolysis sugar yields were calculated by dividing the maximum amount of released sugar (g) by the total amount of polymeric sugars available in the waterinsoluble solid (WIS) fraction of the pre-treated wheat straw. Ethanol yields were calculated by dividing the total amount of ethanol produced by the total amount of fermentable sugars available in the added liquids and solids. Cell yields were based on the total cell dry weight or OD produced per total sugar available or consumed, as indicated in the text. The average cell production rate was estimated based on the total cell dry weight produced per total cultivation time.

\section{Additional files}

Additional file 1: Table S1. Contains experimental results from enzymatic hydrolysis experiments

Additional file 2: Table S2. Contains experimental results from multifeed SSCF experiments

\section{Abbreviations}

CFU: colony forming units; DW: dry weight; FPU: filter paper units; HPLC: high performance liquid chromatography; OD: optical density; SSCF: simultaneous saccharification and co-fermentation; SSF: simultaneous saccharification and fermentation; WIS: water-insoluble solids; YPD: yeast extract, peptone, dextrose medium; $k_{\text {ad: }}$ adsorption rate constant ( $g$ solid FPU ${ }^{-1} \mathrm{~h}^{-1}$ ); $k$ : hydrolysis rate constant (g cellulose $\mathrm{FPU}^{-1} \mathrm{~h}^{-1}$ ); $K$ : saturation constant of glucose uptake $\left(\mathrm{g} \mathrm{L}^{-1}\right) ; K_{\mathrm{G}}$ : inhibition constant of glucose in cellulose hydrolysis $\left(\mathrm{g} \mathrm{L}^{-1}\right) ; K_{\mathrm{iEtOH}}$ : inhibition constant of ethanol in cellulose hydrolysis $\left(\mathrm{g} \mathrm{L}^{-1}\right) ; q_{\mathrm{G}}$ : specific glucose uptake rate by yeast $\left(\mathrm{g} \mathrm{g}^{-1} \mathrm{~h}^{-1}\right) ; Y_{\text {EtOH: }}$ : ethanol yield on glucose $\left(\mathrm{g} \mathrm{g}^{-1}\right)$; a: pre-exponential factor of the ethanol-induced death rate coefficient $\left(\mathrm{h}^{-1}\right)$; $\beta$ : exponential factor of the ethanol-induced death rate coefficient $\left(\mathrm{L} \mathrm{g}^{-1}\right) ; \gamma$ : proportionality factor between xylan and cellulose degradation $(-) ; \varphi$ : fraction of cellulose that has been solubilized $\left(\% \mathrm{~g} \mathrm{~g}^{-1}\right)$.

\section{Authors' contributions}

RW conceived and designed the study, performed the mathematical modelling, performed experiments, analysed and interpreted data and wrote the manuscript. PU designed the study, performed experiments, analysed and interpreted data. CJF conceived and designed the study, interpreted data and wrote the manuscript. All authors read and approved the final manuscript.

\section{Author details}

${ }^{1}$ Division of Industrial Biotechnology, Department of Biology and Biological Engineering, Chalmers University of Technology, Gothenburg, Sweden. ${ }^{2}$ Present Address: National Center for Genetic Engineering and Biotechnology (BIOTEC), Pathum Thani, Thailand.

\section{Acknowledgements}

This study was funded by the Swedish Energy Agency, grant number P37353-1 and by the Chalmers Energy Initiative (http://www.chalmers.se/en/ areas-of-advance/energy/cei/). We are grateful to Lisbeth Olsson and Rakesh Koppram for support in early project development. 


\section{Availability of data and material}

Data will be made available upon request.

\section{Competing interests}

The authors declare they have no competing interests.

\section{Funding}

This study was funded by the Swedish Energy Agency, grant number P37353-1 and by the Chalmers Energy Initiative (http://www.chalmers.se/en/ areas-of-advance/energy/cei/). The funding bodies had no influence on the design of the study and were involved neither in the collection, analysis and interpretation of data, nor in the writing of the manuscript.

Received: 3 February 2016 Accepted: 1 April 2016

Published online: 18 April 2016

\section{References}

1. Wingren A, Galbe M, Zacchi G. Techno-economic evaluation of producing ethanol from softwood: comparison of SSF and SHF and identification of bottlenecks. Biotechnol Progr. 2003;19:1109-17.

2. Olofsson $\mathrm{K}$, Wiman M, Lidén G. Controlled feeding of cellulases improves conversion of xylose in simultaneous saccharification and co-fermentation for bioethanol production. J Biotechnol. 2010;145:168-75.

3. Sassner P, Galbe M, Zacchi G. Techno-economic evaluation of bioethanol production from three different lignocellulosic materials. Biomass Bioenergy. 2008;32:422-30

4. Sassner P, Galbe M, Zacchi G. Bioethanol production based on simultaneous saccharification and fermentation of steam-pretreated Salix at high dry-matter content. Enzyme Microb Technol. 2006:39:756-62.

5. Georgieva TI, Hou XR, Hilstrom T, Ahring BK. Enzymatic hydrolysis and ethanol fermentation of high dry matter wet-exploded wheat straw at low enzyme loading. Appl Biochem Biotechnol. 2008;148:35-44.

6. Bertilsson M, Olofsson K, Liden G. Prefermentation improves xylose utilization in simultaneous saccharification and co-fermentation of pretreated spruce. Biotechnol Biofuels. 2009:2:8.

7. Hoyer K, Galbe M, Zacchi G. Production of fuel ethanol from softwood by simultaneous saccharification and fermentation at high dry matter content. J Chem Technol Biotechnol. 2009;84:570-7.

8. Janssen M, Tillman A-M, Cannella D, Jørgensen $\mathrm{H}$. Influence of high gravity process conditions on the environmental impact of ethanol production from wheat straw. Bioresour Technol. 2014;173:148-58.

9. Wang R, Koppram R, Olsson L, Franzén CJ. Kinetic modeling of multi-feed simultaneous saccharification and co-fermentation of pretreated birch to ethanol. Bioresour Technol. 2014:172:303-11.

10. Koppram R, Olsson L. Combined substrate, enzyme and yeast feed in simultaneous saccharification and fermentation allow bioethanol production from pretreated spruce biomass at high solids loadings. Biotechnol Biofuels. 2014;7:54

11. Koppram R, Nielsen F, Albers E, Lambert A, Wannstrom S, Welin L, Zacchi $\mathrm{G}$, Olsson L. Simultaneous saccharification and co-fermentation for bioethanol production using corncobs at lab PDU and demo scales. Biotechnol Biofuels. 2013;6:2.

12. Hoyer K, Galbe M, Zacchi G. Effects of enzyme feeding strategy on ethanol yield in fed-batch simultaneous saccharification and fermentation of spruce at high dry matter. Biotechnol Biofuels. 2010;3:14

13. Hodge DB, Karim MN, Schell DJ, McMillan JD. Model-based fed-batch for high-solids enzymatic cellulose hydrolysis. Appl Biochem Biotechnol. 2009;152:88-107

14. Liu ZL. Molecular mechanisms of yeast tolerance and in situ detoxification of lignocellulose hydrolysates. Appl Microbiol Biotechnol. 2011;90:809-25
15. Tomás-Pejó E, Olsson L. Influence of the propagation strategy for obtaining robust Saccharomyces cerevisiae cells that efficiently co-ferment xylose and glucose in lignocellulosic hydrolysates. Microb Biotechnol. 2015;8:999-1005

16. Alkasrawi M, Rudolf A, Lidén G, Zacchi G. Influence of strain and cultivation procedure on the performance of simultaneous saccharification and fermentation of steam pretreated spruce. Enzyme Microb Technol. 2006;38:279-86.

17. Almeida JRM, Modig T, Petersson A, Hahn-Hägerdal B, Lidén G, GorwaGrauslund MF. Increased tolerance and conversion of inhibitors in lignocellulosic hydrolysates by Saccharomyces cerevisiae. J Chem Technol Biotechnol. 2007:82:340-9.

18. Van Hoek P, Van Dijken JP, Pronk JT. Effect of specific growth rate on fermentative capacity of baker's yeast. Appl Environ Microbiol. 1998;64:4226-33.

19. Yarbrough JM, Mittal A, Mansfield E, Taylor LE, Hobdey SE, Sammond DW, Bomble YJ, Crowley MF, Decker SR, Himmel ME, Vinzant TB. New perspective on glycoside hydrolase binding to lignin from pretreated corn stover. Biotechnol Biofuels. 2015;8:214.

20. Unrean P, Khajeeram S, Laoteng K. Systematic optimization of fed-batch simultaneous saccharification and fermentation at high-solid loading based on enzymatic hydrolysis and dynamic metabolic modeling of Saccharomyces cerevisiae. Appl Microbiol Biotechnol. 2015;100:2459-70.

21. Xiros C, Olsson L. Comparison of strategies to overcome the inhibitory effects in high-gravity fermentation of lignocellulosic hydrolysates. Biomass Bioenergy. 2014;65:79-90.

22. Beckner M, Ivey ML, Phister TG. Microbial contamination of fuel ethanol fermentations. Lett Appl Microbiol. 2011;53:387-94.

23. Westman JO, Mapelli V, Taherzadeh MJ, Franzen CJ. Flocculation causes inhibitor tolerance in Saccharomyces cerevisiae for second-generation bioethanol production. Appl Environ Microbiol. 2014;80:6908-18.

24. Sluiter A, Hames B, Ruiz R, Scarlata C, Sluiter J, Templeton D, Crocker D. Determination of structural carbohydrates and lignin in biomass: Laboratory Analytical Procedure (LAP) (Revised August 2012). Issue Date: 4/25/2008. NREL/TP-510-42618. http://www.nrel.gov/docs/gen/ fy $13 / 42618 . p d f$

25. Adney B, Baker J. Measurement of cellulase activities: Laboratory Analytical Procedure (LAP). Issue Date 08/12/1996, NREL/TP-510-42628. http:// www.nrel.gov/docs/gen/fy08/42628.pdf.

26. Xiao Z, Storms R, Tsang A. Microplate-based filter paper assay to measure total cellulase activity. Biotechnol Bioeng. 2004;88:832-7.

27. Tomás-Pejó E, Bonander N, Olsson L. Industrial yeasts strains for biorefinery solutions: constructing and selecting efficient barcoded xylose fermenting strains for ethanol. Biofuels Bioprod Bioref. 2014:8:626-34.

28. Verduyn C, Postma E, Scheffers WA, Van Dijken JP. Effect of benzoic acid on metabolic fluxes in yeasts: a continuous-culture study on the regulation of respiration and alcoholic fermentation. Yeast. 1992:8:501-17.

29. Zhang JY, Shao XJ, Townsend OV, Lynd LR. Simultaneous saccharification and co-fermentation of paper sludge to ethanol by Saccharomyces cerevisiae RWB222-Part I: kinetic modeling and parameters. Biotechnol Bioeng. 2009:104:920-31.

\section{Submit your next manuscript to BioMed Central and we will help you at every step:}

- We accept pre-submission inquiries

- Our selector tool helps you to find the most relevant journal

- We provide round the clock customer support

- Convenient online submission

- Thorough peer review

- Inclusion in PubMed and all major indexing services

- Maximum visibility for your research

Submit your manuscript at www.biomedcentral com/submit
C Biomed Central 